\title{
Effect of die shape on the metal flow pattern during direct extrusion $\operatorname{process}^{(\bullet)}$
}

\author{
N. Solomon* and I. Solomon**
}

\begin{abstract}
The geometric shape of the tools is the main factor by which an optimum technological process can be developed. In the case of extrusion process the strain distribution and other important variables that influence material structure, such as hydrostatic stress, are strongly dependent on the geometry of the die. Careful design of the extrusion die profile can therefore control the product structure and can be used to minimise the amount of inhomogeneity imparted into the product. A possibility to minimise the amount of product inhomogeneity is the using of a flat die with a fillet radius in front to the bearing surface with leads to a minimum dead zone and consequently to a minimum friction at billet-container interface. In the case of aluminium alloy type 2024, for an extrusion ratio of R=8.5, good results were obtained with a fillet radius of $3.0 \mathrm{~mm}$. The experimental data have been used for the finite element numerical simulation of the extrusion process. The data obtained by numerical simulation with FORGE2 programme confirm the theoretical and experimental outcomes. The aim of this paper is to study the influence of such flat die on the material flow during direct extrusion process and consequently on extruded product microstructure and mechanical properties.
\end{abstract}

\section{Efecto de la forma del molde sobre el flujo de metal durante el proceso de extrusión directa}

\begin{abstract}
Resumen
La forma geométrica de las herramientas es el principal factor a través del cual un proceso óptimo de deformación plástica puede ser mejor desarrollado. En el caso del proceso de extrusión, la distribución de la deformación y otras variables importantes, como la presión hidrostática, que pueden influir en la estructura del material, son fuertemente dependientes de la geometría del molde. Mediante un diseño apropiado del perfil del molde de extrusión se pueden controlar la estructura y las propiedades mecánicas del producto y, por lo tanto, se puede utilizar para minimizar la cantidad de la no homogeneidad del producto. Una posibilidad para reducir al mínimo la cantidad de no homogeneidad del producto es utilizar un molde recto provisto de un radio de conexión en la zona de deformación, que puede causar una reducción al mínimo de la zona muerta y, así, reducir al mínimo la fricción en la interfase entre el semiacabado y el contenedor del molde. En el caso de la aleación de aluminio de tipo 2024, para una relación de extrusión, R = 8,5 , los mejores resultados se obtuvieron con un radio de conexión de $3,0 \mathrm{~mm}$. Los datos experimentales se utilizaron para la simulación numérica del proceso de extrusión. Los resultados experimentales obtenidos mediante el uso de simulación numérica con el programa FORGE2 confirman los resultados teóricos y experimentales. El propósito de este trabajo es estudiar la influencia de este tipo de matrices con un radio de conexión en la zona de deformación en el flujo de material durante el proceso de extrusión y por tanto en la microestructura y propiedades mecánicas del producto extruido.
\end{abstract}

Palabras clave

Patrón de flujo de metales; Molde plano; Fricción; Elementos finitos; Cepa equivalente.

\section{INTRODUCTION}

Both the quality and accuracy of the extruded parts depend on a large range of factors such as: the type of the material being deformed, the way of its flowing during the deformation process, the type of the tools material, the stress state, the working temperature, the friction conditions, the type of the lubricants and how they are used etc. ${ }^{[1-4]}$.

(•) Trabajo recibido el día 5 de Junio de 2009 y aceptado en su forma final el día 20 de Abril de 2010.

* "Stefan cel Mare" Suceava University, Str. Universitatii nr.13, 720228 Suceava, Romania.

** "Dunarea de Jos" Galati University, Str. Domneasca nr.47, 6200 Galati, Romania. 
Due to friction the metal in the outer layer of the billet moves much slower than that in the centre ${ }^{[5]}$. Therefore, it is observed that deformation is the result of relative displacements which lead to shearing between the adjacent layers of material. The most deformed metal layers in the final product are those located between the outer surface and the half of the radius of the extruded product. The intensity of deformation of central layers is often twice smaller than that of the layers located close to the surface. This flow mechanism leads to a considerable differentiation of the strain fields within the billet, and finally causes the non-uniform distribution of the total strain, microstructure and properties of the material over the product cross-section.

A large number of the publications dealing with the influence of the metal flow pattern on the microstructure and mechanical properties of extruded products has been published, among which works by Sheppard ${ }^{[4]}$, Kusiak et al. ${ }^{[6]}$, Libura et al. ${ }^{[7}$ and 8$]$ are worth mentioning.

In the extrusion practice of the metallic materials the die geometric shape may influence the technological process development, and together with technological parameters contribute to the products proper quality $[7,9$ and 10$]$. The geometric shape of the tools is the main factor by which an optimum technological process is developed. The process is considered to have an optimal development if the material flow speed in the deformation zone is as uniform as possible, if at least in the deformation zone the stress diagram is close to the compression three axial diagram and lastly, if the extrusion pressure values are as low as possible.

Kazanowski et al..$^{[11]}$, carried out experiments on convex dies and concluded that this kind of dies outperform the flat face dies only for extrusion ratios below 30. According to Tokizawa et al. ${ }^{[12]}$, when the die semi-angle becomes larger, the pressure acting on the bearing surface tends to decrease. For $90^{\circ}$ die semi-angle the best extrudability was attained, and therefore the 90 die was concluded to be most suitable die for hot extrusion in terms of extrudability and die performance. It might come from reduced frictional resistance of the metal flow during extrusion process. A large die angle causes more turbulence in the metal flow during reduction, leading to decreased friction at the die - billet interface ${ }^{[13]}$. According to Totten et al. ${ }^{[5]}$ a small reduction ratio will yield a smaller dead zone close to the die, and consequently a reduction of the frictional resistance of the metal flow during extrusion process.

In case of the deep drawing process, to prevent wrinkling appearance and to control the material flow through a constricted space in the deformation zone, the punch and the draw-die must have a fillet radius instead of sharp corners ${ }^{[13}$ and 14$]$. Therefore, I considered that similar to the die used for deep drawing process, a flat die with a fillet radius in front of bearing surface will lead to a uniform material flow during extrusion process.

Taking into account the above mentioned, the aim of this paper is to study the influence of such flat die on the material flow during extrusion process. This method can be used to control the material's microstructure and mechanical properties of final products.

\section{EXPERIMENTAL PROCEDURE}

From an analytical point of view the material flow due to direct and/or indirect extrusion is a very complex approach. There are many methods available for obtaining a picture of the material flow during deformation process. Two of the most powerful methods to obtain a detailed flow pattern to be discussed are visioplasticity and the finite element method.

The experimental researches were focused on two directions:

- the influence of the die shape on the metal flow pattern during extrusion process;

- the influence of the viscous state material extrusion on the quality of the deformed product.

However, in this paper only the influence of the die geometric shape and the appropriate positioning of the dead zone over metal flow pattern will be presented.

The influence of the die geometric shape on the metal flow pattern during extrusion process was studied using visioplasticity method and a die set with different shapes: conical, flat and convex ${ }^{\text {[7, } 9 \text { and 15-17] }}$. The strain analysis was performed on the basis of the extrusion tests. The lead ( $\mathrm{Pb99.5)}$ samples were used to investigate the influence of the fillet radius of a flat die on the strain field and consequently on the metal flow during direct extrusion, because it satisfies both commercial and technological conditions of material testing. Commercial because the investigations on the lead $(\mathrm{Pb99.5)}$ are cheaper than ones on the aluminum alloys and technological because it satisfies both rheological and thermomechanical conditions of aluminium alloys extruded at hot temperature $\left(400 \div 500{ }^{\circ} \mathrm{C}\right)$.

Conform to similitude theory a model is said to have similitude with real application if the two share geometric, kinematic and dynamic similarity. During 
hot extrusion the aluminum alloy 2024 is continually recrystallized. At room temperature lead $(\mathrm{Pb})$ is well above its recrystallization temperature of $-4^{\circ} \mathrm{C}$ and therefore it continuously recrystallizes and does not strain harden and remain soft and ductile ${ }^{[18]}$.

The strain hardening curve of the lead determined from the tension tests was:

$$
\sigma_{\mathrm{p}}=7+33 \cdot \dot{\varepsilon}^{0.1546} \cdot \varepsilon^{0.2445}
$$

where:

$$
\begin{aligned}
& -\sigma_{\mathrm{p}}-\text { yield stress; } \\
& -\dot{\varepsilon}-\text { strain rate; } \\
& -\varepsilon-\text { strain. }
\end{aligned}
$$

The working conditions of the extrusion tests were the following:

- extrusion temperature: $20^{\circ} \mathrm{C}\left(293^{\circ} \mathrm{K}\right)$;

- sample dimensions:

- length, $\mathrm{H}=75 \mathrm{~mm}$;

- billet diameter, $\mathrm{D}_{\mathrm{o}}\left(2 \mathrm{R}_{\mathrm{o}}\right)=45 \mathrm{~mm}$;

- product diameter, $\mathrm{D}_{\mathrm{f}}\left(2 \mathrm{R}_{\mathrm{f}}\right)=10$ and $20 \mathrm{~mm}$;

- extrusion ratio $\left(R=\frac{R^{2} \mathrm{O}}{\mathrm{R}_{\mathrm{f}}^{2}}\right), \mathrm{R}=5.06$ and
- die angle, $\alpha_{d}: 45^{\circ}, 60^{\circ}, 90^{\circ}, 105^{\circ}, 120^{\circ}$ and $135^{\circ}$;

- fillet radius, $\mathrm{r}_{\mathrm{f}}: 0,1.5,3,4.5 \mathrm{~mm}$.

The extrusion loads were monitored in all the tests. Additionally, some of the samples which were extruded had a square grid $4 \times 4 \mathrm{~mm}$ drawn at their longitudinal cross section, as it is shown in figure 1. These samples were used for the investigation of the flow pattern during the extrusion. The strain field was determined using the visioplasticity method ${ }^{[4 \text { and } 6]}$, in which the strain tensor components are calculated from the measurements of the coordinates of nodes for the initial grid and for the deformed grid obtained by an interruption of the process when the marked part of the billet was in the die.

In order to point out the influence of the fillet radius in the case of a flat die the experimental researches on lead $(\mathrm{Pb} 99.5)$ were followed by experiments on the aluminum alloy type $\mathrm{AlCu} 4 \mathrm{Mg}$. The aluminum alloy samples were deformed in the following conditions:

- extrusion temperature: $450^{\circ} \mathrm{C}(723 \mathrm{~K})$,

- extrusion ratio, $\mathrm{R}=8.5$;

- die angle, $\alpha_{\mathrm{d}}=90^{\circ}$;

- fillet radius, $\mathrm{r}_{\mathrm{f}}: 3 \mathrm{~mm}$;

- extrusion velocity, $\mathrm{u}_{0}=1.2 \mathrm{~mm} / \mathrm{s}$.

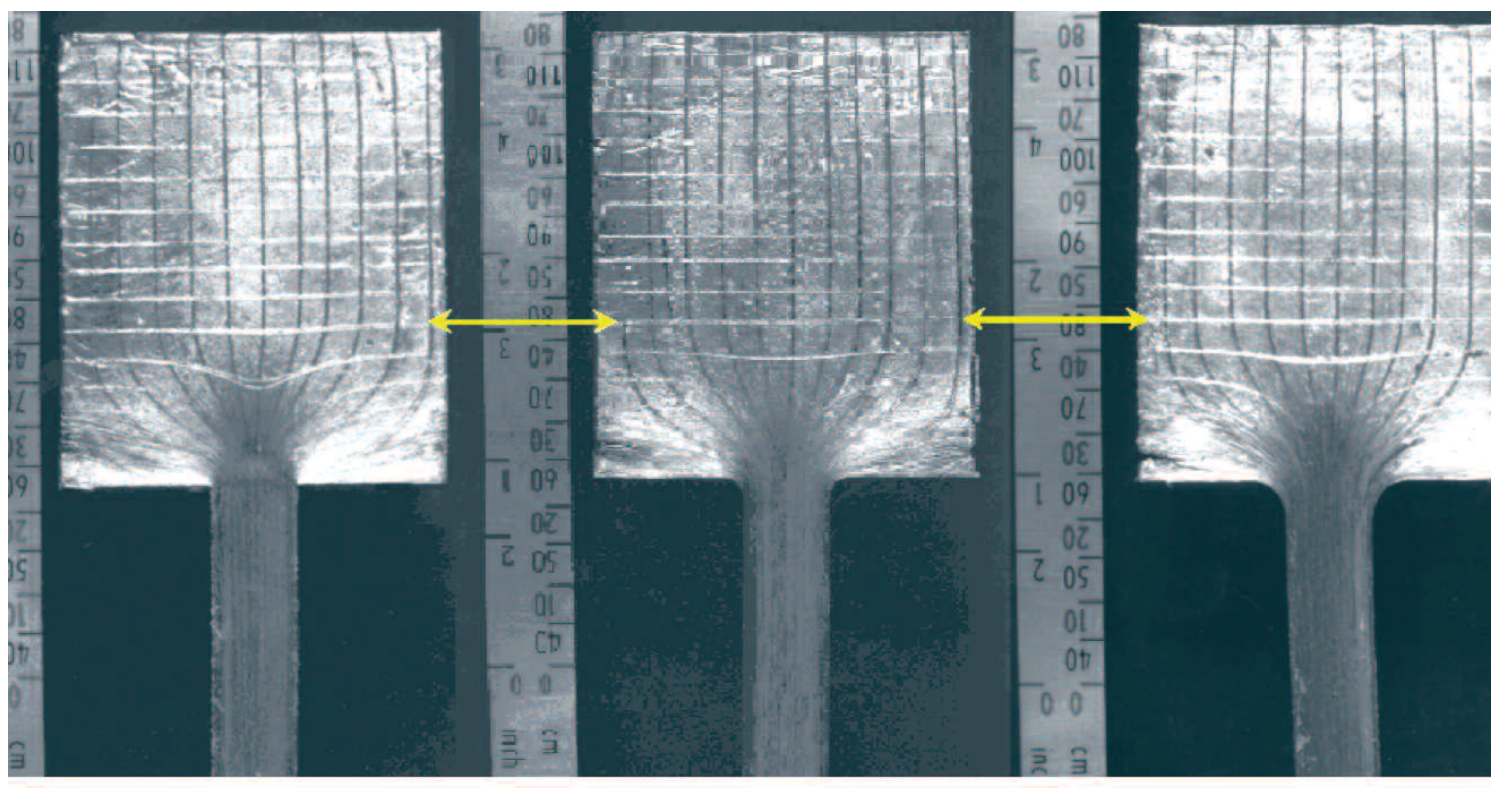

a)

b)

c)

Figure. 1. Experimental investigations of metal flow: a) typical flat die; b) flat die with fillet radius, $r_{\mathrm{f}}=3 \mathrm{~mm} ; \mathrm{c}$ ) flat die with fillet radius of $r_{\mathrm{f}}=4.5 \mathrm{~mm}$.

Figura. 1. Investigaciones experimentales del flujo de metal: a) molde plano típico; b) molde plano con el radio del prendedero, $r_{f}=3 \mathrm{~mm}$; c) molde plano con el radio del prendedero, $r_{f}=4.5 \mathrm{~mm}$. 
The structural modifications of $\mathrm{AlCu} 4 \mathrm{Mg}$ aluminium alloy occurred during the extrusion process were investigated in detail.

\section{CALCULATION PROCEDURE}

The pattern of material flow during the extrusion process was also analysed by the finite element method using the commercial code FORGE2 ${ }^{\circledR}$ developed by CEMEF, Sophia Antipolis, France ${ }^{[6,9}$, 19 and 20]. This program is oriented towards the thermomechanical finite element modelling of the axissymmetric forging as well as the plane state forging.

The axis-symmetrical version of the simulation program FORGE $2{ }^{\circledR}$ has been used to simulate forward hot extrusion of $\mathrm{AlCu} 4 \mathrm{Mg}$ alloy. Briefly, the rheological parameters of material within FORGE2 ${ }^{\circledR}$ are described by Norton-Hoff law, written as follows:

$$
\mathrm{s}=2 \mathrm{k}(\sqrt{3} \dot{\bar{\varepsilon}})^{\mathrm{m}-1} \dot{\varepsilon}
$$

where:

$$
\begin{aligned}
& \mathrm{s}-\text { deviator stress tensor; } \\
& \bar{\varepsilon} \text { - effective strain rate; } \\
& \dot{\varepsilon}-\text { strain rate tensor. }
\end{aligned}
$$

$\mathrm{K}$ and $\mathrm{m}$ are material consistence and strain sensitivity coefficient respectively. Generally both are functions of temperature $T$ and equivalent strain $\bar{\varepsilon}$. In order to define the material consistence in FORGE2 ${ }^{\circledR}$ program, the strain hardening power was used. The billet was modelled by means of second

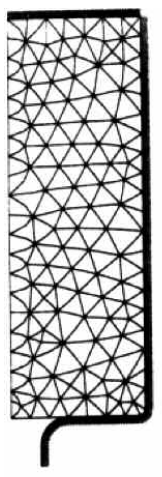

a)

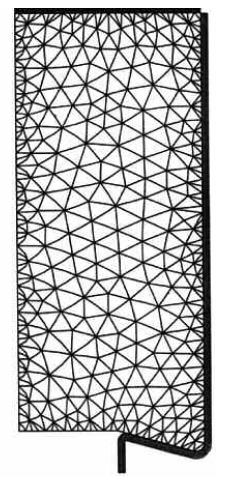

b)
Figure. 2 Billet automatic meshing and remeshing: a) flat die fillet radius; b) convex die.

Figura. 2 Billet automática de mallado y remeshing: a) molde plano con el radio del prendedero; b) molde convexo. order triangular elements with 6 nodes (Fig. 2). Automatic procedure to create a mesh and to perform a remeshing was used. The Newton- Raphson method was applied to solve the equations system.

\section{RESULTS AND DISCUSSION}

The material flow during the deformation process considerably affects the product quality - its structure and properties, the process efficiency and the deformation force size. In terms of optimisation of the material flow during deformation process the most favourable technological variant is the one which generates a uniform distribution of the particle velocities in the die opening $[6,7$ and 9$]$.

Figure 3 shows the microstructure evolution of the hot-extruded aluminum alloy type 2024 ( $\mathrm{AlCu} 4 \mathrm{Mg}$ ) in longitudinal section. The etching reagent: $0.5 \mathrm{ml}$ flourine hydride, $15 \mathrm{ml}$ chlorine

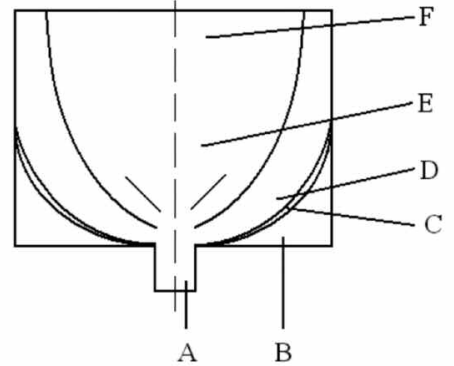

B
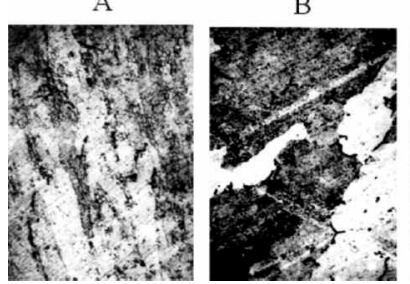

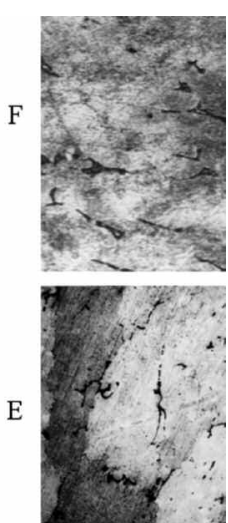

C

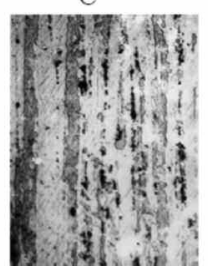
D

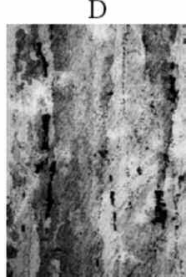

Figure. 3. Evolution microstructure during hot extrusion process: A - deformed product; B dead material zone; $\mathrm{C}$ - shear zone; $\mathrm{D}$ - zone intimate to C; E - central deformation zone; $\mathrm{F}$ - undistorted material.

Figura. 3. Evolución de la microestructura durante el proceso de extrusión en caliente: $A$ - producto deformado; B - zona muerta; $C$ - zona cizallada; $D$ - zona íntima a $C$; $E$ - zona central de la deformación; F- material no deformado. 
hydride, $25 \mathrm{ml}$ azotic acid and $95.5 \mathrm{ml}$ water was used to reveal the structure.

The initial dendritic cast microstructure from the central upper part $(\mathrm{E}, \mathrm{F})$ of the billet is recovered also in the undistorted dead zone (B). The increasing of the extrusion force, in the first step of the deformation process, is due to not only to the friction forces between billet and container but also due to the shearing forces which appear in zone C (Fig. 3) between the undistorted material (E, F) and dead zone (B). Here, like in the nearest zone (D), the material is strongly deformed. Following to the shearing, a sliding process between the formed dead zone (B) and undistorted material (E, F) will take place until the end of the extrusion process. This zone can be considered at the periphery of the deformed zone. The material type and the local friction conditions can influence its form, as well as its thickness. In some cases of hot extrusion of both aluminium and aluminium alloys (i.e.
$\mathrm{AlCu} 4 \mathrm{Mg}$ ), these lead to an extensive grain growth in the peripheral layer of extruded product ${ }^{[6,7,9}$ and 10].

The metal flow pattern which determines strain distribution, material microstructure and mechanical properties over the product cross-section can be influenced by the local friction conditions and consequently by the material state, the die geometric shape and by the size and appropriate positioning of the dead zone (Fig. 4). The set of extrusion tools, die, container and ram, must be built to limit the friction with the billet. This is because the friction during the deformation process has a high influence on the occurrence of defects in the extruded products.

Figure 4 shows the material flow pattern for typical conical, flat and convex dies and for a flat die with a fillet radius in front of the bearing surface. In all cases the deformation zones are delimited by the velocity discontinuity surfaces, $\Gamma_{1}$ and $\Gamma_{2}$. The material from outer layers of the billet, in the deformation zone,
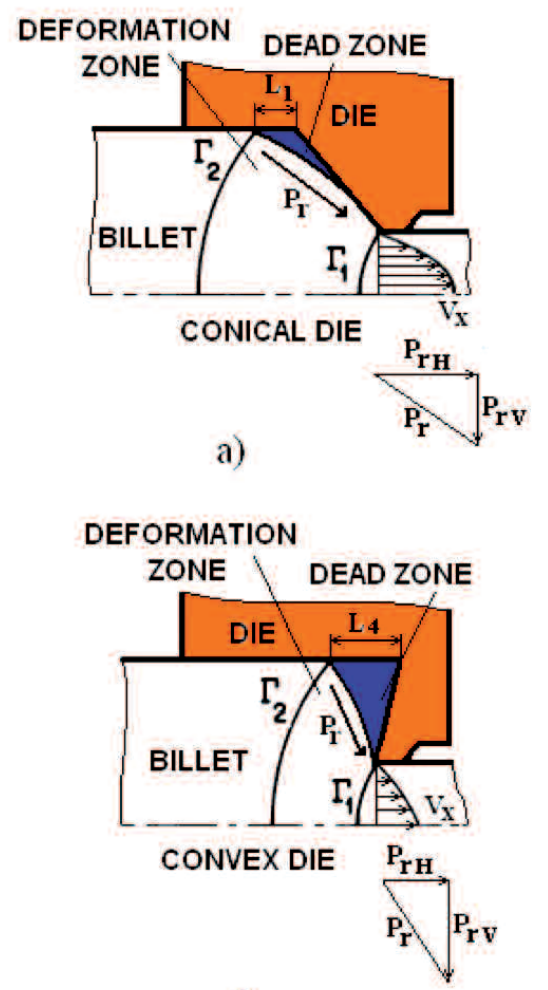

c)
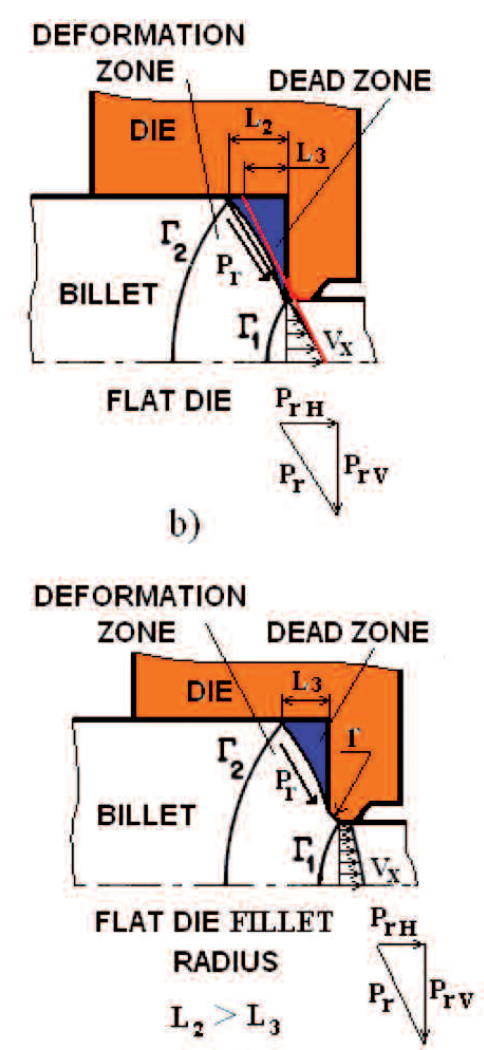

d)

Figure. 4. Theoretical investigations of metal flow: a) conical die; b) flat die; c) convex die; d) flat die with fillet radius; $V_{x}-$ velocity diagram; $\Gamma_{1}, \Gamma_{2}-$ velocity discontinuity surfaces, $\mathrm{P}_{\mathrm{r}}$ - radial pressure.

Figura. 4. Investigaciones teóricas del flujo de metal: a) molde cónico; b) molde plano; c) molde convexo; d) molde plano con el radio del prendedero; $V_{x}$ - diagrama de velocidad; $\Gamma_{1}, \Gamma_{2}$ - superficies de la discontinuidad de la velocidad; $P_{r}$ - presión radial. 
is moving in radial direction under the $\mathrm{P}_{\mathrm{r}}$, which is the resultant force of all component forces acting in this area. In the case of typical dies during extrusion process the material from the centre moves faster than that from the outer surface. This kind of material flow leads to a strong material inhomogeneity. A strong influence on the radial metal flow has the vertical component $\mathrm{P}_{\mathrm{rv}}$ of the resultant force $\mathrm{P}_{\mathrm{r}}$, which in the case of a flat die with a fillet radius has the biggest value due to the size and position of dead zone within the deformation zone.

In the case of extrusion with a flat or convex die the radial metal flow dominates the deformation zone. Such mode of metal flow results in an increment of the hydrostatic pressure in the lowest part of the deformation zone, which was confirmed also by the calculations. It also determines a more uniform distribution of metal velocity and strain at the moment of exit from the die.

Based on the upper bound method the optimum value of the fillet radius was determined, in such a way that the relative pressure to be a minimum one [9]:

$$
\frac{\partial\left(\frac{p_{F}}{\sigma_{0}}\right)}{\partial r_{f}}=0, \text { that is: } r_{f}=k^{*}\left(R_{f} / 2\right)
$$

where:

$\mathrm{k}=1.2-1.85$, correction coefficient (the material was considered homogeneous, isotropic and perfectly plastic);

$-\mathrm{p}_{\mathrm{F}}$ - deformation pressure;

- $\mathrm{D}_{\mathrm{f}}=2 * \mathrm{R}_{\mathrm{f}}$ - product diameter;

$-\sigma_{\mathrm{o}}-$ yield strength;

$-\mathrm{r}_{\mathrm{f}}-$ fillet radius.

The theoretical investigations (Fig. 4) and experimental results obtained on lead with different dies showed that the most favourable flow pattern was obtained in the case of a flat die with fillet radius of $r_{f}=3 \mathrm{~mm}$, presented in figure 1 . At the same level, in the centre of the billet closed to lowest part of the deformation zone, one can see that the distorted grid lines in the case of a typical flat die (Fig. 1 a)) move much faster - almost twice, than those in the case of a flat die with fillet radius (Fig. 1 b)). The lowest inhomogeneity was obtained for the fillet radius of $r_{f}$ $=3.0 \mathrm{~mm}$, then it starts to increase slightly again (Fig. $1 \mathrm{c})$ ). The reduction of the dead zone size or its favourable positioning (Fig. $4 \mathrm{~d}$ )) could ensure a metal radial flow resulting in a decreasing of the friction, and implicitly of the deformation non-uniformity.

The microstructures of the 2024 aluminum alloy (type $\mathrm{AlCu} 4 \mathrm{Mg}$ ) are shown in the optical micrographs
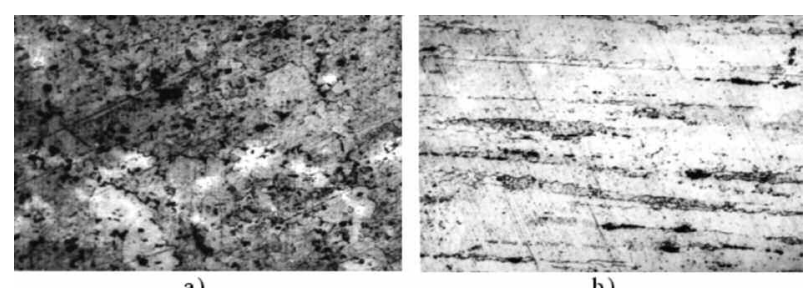

a)

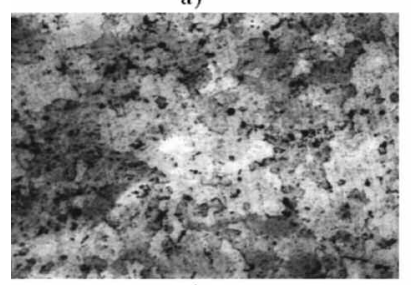

c)

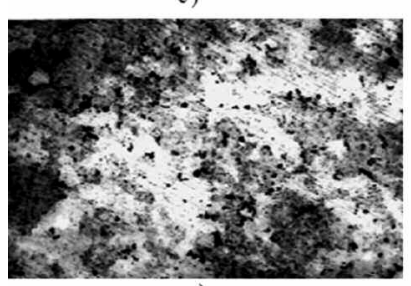

e)

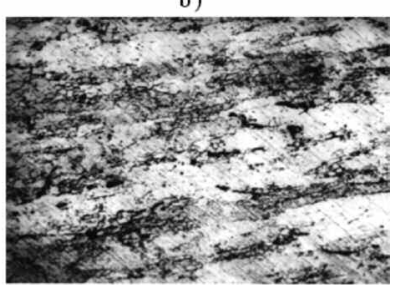

d)

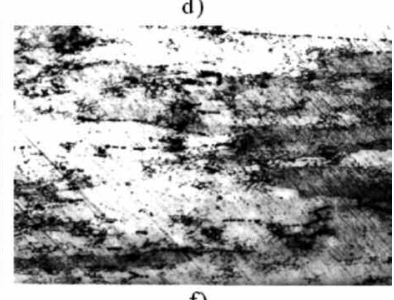

f)

Figure. 5. Structural aspects (200X) of hot extruded aluminium alloy type $\mathrm{AlCu}_{4} \mathrm{Mg}(2024)$ as follows: a), c), e) - cross section; b), d), f) - longitudinal section: a), b) - located close to the outer surface; c), d) - located between a), e) and b), f), respectively; e), f) - located in the centre of product.

Figura. 5. Aspectos estructurales de aleación de aluminio de extrusión en caliente tipo $\mathrm{AlCu} 4 \mathrm{Mg}$ (2024) de la siguiente manera: a), c), e) - sección transversal, b), d), f) - sección longitudinal: a), b) - ubicado cerca de la superficie, c), d) - situado entre un a), e) y b), f), respectivamente; e), f) - situado en el centro de producto.

in figure $5 \mathrm{a}$ )-f). In cross section, figure 5 a), c), e), the structure is as uniform as possible. This is due to the radial metal flow pattern induced by the fillet radius. In the case of the extrusion with a flat die with a fillet radius the radial metal flow dominates the deformation zone and therefore the material structure in cross section will be more uniform. In longitudinal section it can be seen that the most deformed metal layers in the final product are those located between the outer surface and the half of the radius of the extruded product.

In the case of a flat die with fillet radius it doesn't mean that its presence will lead to an increase of material velocity in the exit opening of the die. The main effect of the fillet radius consists in a more uniform velocity in a cross section of extruded material (Figs. 1 and 6). The presence of a fillet radius 

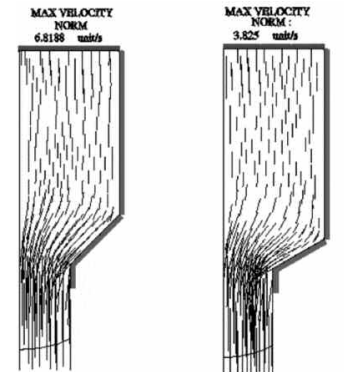

a)

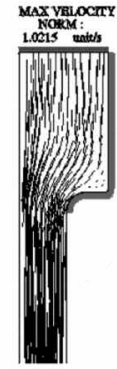

b)

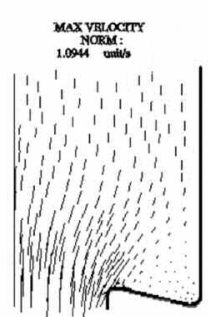

c)
Figure. 6. Calculated velocity field during extrusion through conical dies: a) typical conical dies; b) flat die with fillet radius, $r_{r}=3 \mathrm{~mm}$; $)$ convex die.

Figura. 6. Campo de velocidad calculada durante la extrusión por moldes cónicos: a)molde cónico típico; b) molde plano con el radio del prendedero, $r_{f}=3 \mathrm{~mm}$; c) molde convexo.

will introduce a radial pressure $\mathrm{P}_{\mathrm{r}}$ which will delay the material flow from the center of the product and consequently the intensity of deformation of central layers will be very close to those from the outer surface. In this way the product structure and properties can be controlled.

The results of tensile tests performed on samples of 2024 - T4 aluminium alloy from the deformation zone $(\mathrm{E})$ and from the deformed product $(\mathrm{A})$, led to the following results: $\mathrm{R}_{\mathrm{m}}=376 \mathrm{MPa}(\mathrm{E})$ and $\mathrm{R}_{\mathrm{m}}=534.5 \mathrm{MPa}(\mathrm{A})$, respectively ${ }^{[21]}$. The microhardness variation has also been measured using

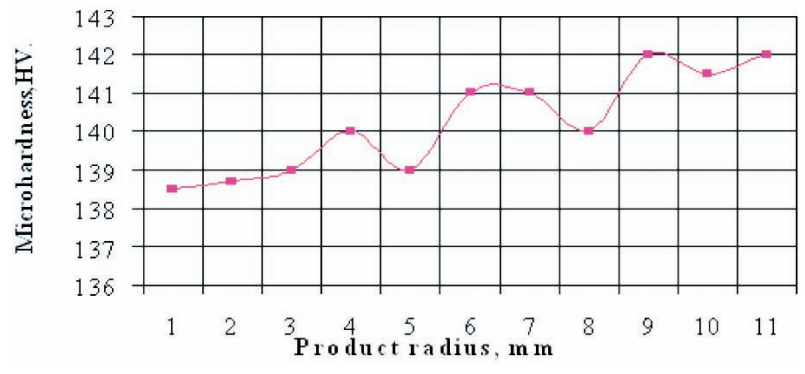

Figure. 7. Microhardness map.

Figura. 7. Mapa de microdureza.

Vickers method with a $50 \mathrm{~g}$ load and it is shown in figure 7. High mechanical properties are attributed to the small variation of the grain size over the cross section of the extruded product ${ }^{[21}$ and 22]. It means that in the case of the flat die with a radius in front of bearing surface, the radial flow of the material prevails inside of the deformation zone.

This material flow pattern determines the increase of the hydrostatic pressure in the lower side of the deformation zone. In the axial-symmetric extrusion process, this determines a more even distribution of the material particles at the moment of leaving the die and consequently a better material homogeneity.

The plots obtained from the finite element simulation ${ }^{[19}$ and $\left.23-25\right]$ are presented in the following figures. Fig. 8 shows calculated distributions of the equivalent strain in the deformation zone. These results agree with the experimental data. The strain

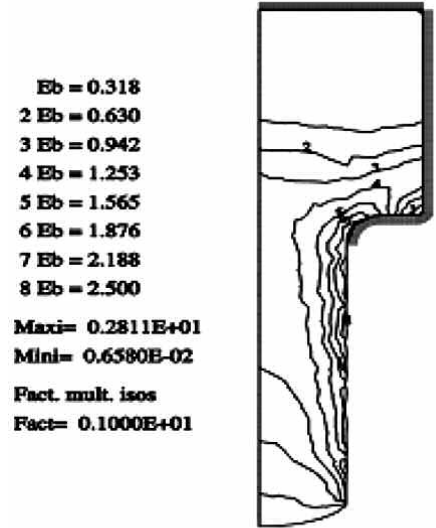

a)

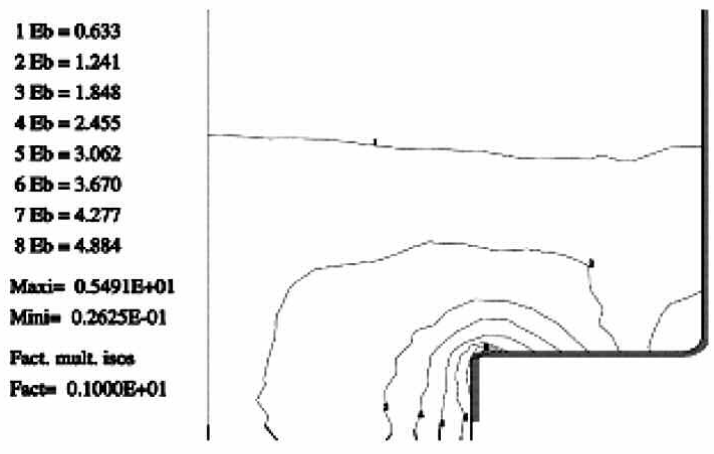

b)

Figure. 8. Calculated equivalent strain during extrusion through a flat die with a fillet radius, $r_{r}=3.0 \mathrm{~mm}(a)$ and $r_{r}=0 \mathrm{~mm}(b)$.

Figura. 8. Tensión equivalente calculada durante la extrusión a través de un molde plano con el radio del prendedero, $r_{f}=3.0 \mathrm{~mm}$ (a) y $r_{f}=0 \mathrm{~mm}$ (b). 


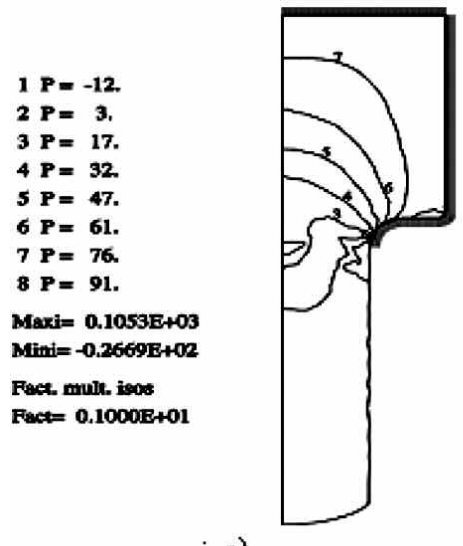

a)
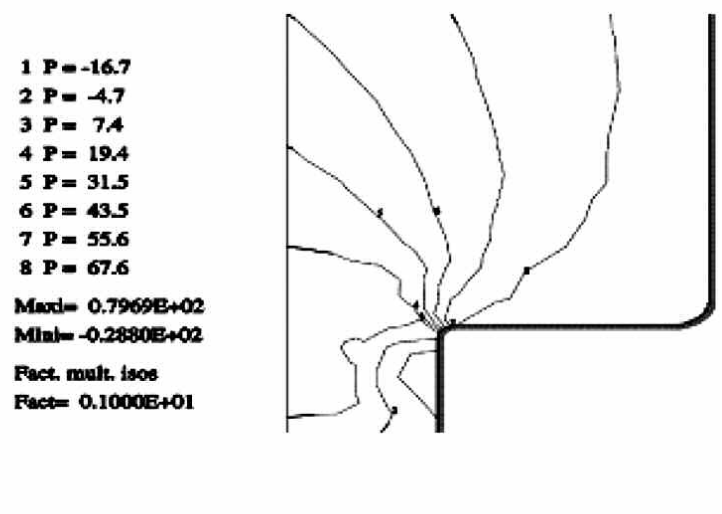

b)

Figure. 9. Calculated hydrostatic pressure during extrusion through a flat die with a fillet radius, $r_{r}=3.0 \mathrm{~mm}(a)$ and $r_{r}=0 \mathrm{~mm}(b)$.

\section{Figura. 9. Presión hidrostática calculada durante la extrusión a través de un molde plano con un radio del prendedero, $r_{f}=3.0 \mathrm{~mm}$ (a) y $r_{f}=0$ $m m(b)$.}

inhomogeneity decreases with the increasing of the fillet radius of the die and the lowest one was obtained for the fillet radius of $r_{f}=3.0 \mathrm{~mm}$. The strain distribution and other important variables that influence material structure, such as hydrostatic stress, are strongly dependent on the geometry of the extrusion dies ${ }^{[26-29]}$. This correlation between die fillet radius and the flow uniformity is also confirmed by the results of calculation of other process parameters like velocity, shown in figure 6 , and hydrostatic pressure, shown in figure 9.

Analysis of the hydrostatic stresses (Fig. 9) shows a strong relation between the hydrostatic pressure and the fillet radius. It can be concluded at this stage that an introduction of a die fillet radius in the axisymmetric extrusion process promotes a more uniform distribution of metal velocity (Fig. 6) and strain (Fig. 8) at the moment of exit from the die. This phenomenon is explained by an increase of the hydrostatic pressure of the metal extruded through a die with a radius comparing to the traditional ones, especially when the extruded materials are difficult to deform.

\section{CONCLUSIONS}

Taking into account the above mentioned results we can conclude:

- by means of a suitable design of the die geometric shape, it is possible to obtain a favourable positioning and/or a dead zone size reduction. This determines an important reduction of the friction in the deformation zone and of the extrusion pressure as well;

- the most favourable extrusion technological variant is the one that determines a uniformisation of the material particle flowing velocity through the deformation zone and consequently a reduction of the structural nonuniformitys;

- the increase of the hydrostatic pressure inside the deformation zone together with a radial flow and an uniformisation of the material flow velocity results in a better metal particle distribution when leaving the die. That fact results in an uniformisation of the grain size within the cross section of the product, and in mechanical properties consequently;

- careful design of the extrusion die profile can therefore control the product structure and can be used to minimise the amount of inhomogeneity imparted into the product.

- the homogeneity and mechanical properties in cross-section of the extruded product can be controlled when a die with a fillet radius in bearing surface is used. In consequence, the quality of the extruded product can be improved;

- analysis of both experimental and theoretical results showed that the strain inhomogeneity decreases with the increasing die fillet radius.

\section{REFERENCES}

[1] P.K. Bakshi and B.P. Kashyap, J. Mater. Sci. 30(1995) 5.295. 
[2] G. Tempus, W. Calles and G. Scharf, Mater. Sci. Technol. 7 (1991) 937-945.

[3] A.K. Mukhopadhyay, H.M. Flower and T. Sheppard, Mater. Sci. Technol. 6 (1990) 611.

[4] T. Sheppard, Mater. Sci. Technol. 9 (1993) 430440.

[5] G.E. Totten and D.S. MacKenzie, Handbook of Aluminum: Physical metallurgy and processes, Marcel Dekker (Ed.), New York, EE. UU., 2003.

[6] J. Kusiak, W. Libura, M. Pietrzyk and N. Solomon, Arch. Metall. 43 (1998) 4-14.

[7] W. Libura, Eng. Trans. 43 (1995) 245-257.

[8] W. Libura, J. Zasadzinski, J. Mater. Process. Tech. 34 (1992) 517.

[9] N. Solomon, PhD Thesis, University of Galati, 1997.

[10] N. Solomon, M. Teodorescu, I Solomon and F. Popescu, 15th Symp. "Danubia-Adria" Bertinoro, Italy, 1998, p. 211.

[11] P. Kazanowski, H.M. Browneb, W. Libura and W.Z. Misiolek, Mat. Sci. Eng. A 404 (2005) 235-243.

[12] M. Tokizawa and N. Takatsuji, Trans. Jpn. Inst. Met. 28 (1987) 994-1.003.

[13] M.P. Groover, Fundamentals of Modern Manufacturing: Materials, Processes, and Systems, $4^{\text {th }}$ ed., World Color, 2009.

[14] D.A. Smith, Die design handbook, Edition: 3 Printed in US, 1990.

[15] W. Johnson, K. Kudo, The mechanics of metal extrusion, Manchester University Press, 1962.

[16] G. Spur, Th. Stöferle, handbuch der
Fertigungstechnik, Band 2/2 Umformen, Carl Hanser Verlag München Wien, 1983.

[17] R.E. Sliwa, Proc. 6 ${ }^{\text {th }}$ ICTP, 1999.

[18] D.R. Askeland, P.P. Phulé, The science and engineering of materials, 5 th ed., Cengage Learning, 2006.

[19] J.L. Chenot, J. Mat. Proc. Tech. 34 (1992) 9.

[20] T. Welo, S. Skjerrvold, O. Jensrud and K. Pedersen, J. Mat. Proc. Tech. 34 (1992) 533.

[21] J. G. Kaufman, Properties of aluminum alloys: tensile, creep, and fatigue data at high and low temperatures, The Aluminium Association, Inc., 1999.

[22] J.R. Davis \& Associates, Aluminium and aluminium alloys, ASM Handbook series, Edition: 5, 1993.

[23] B.R. Tibbett and J. Ting-Yung, IEEE Trans. Cont. Syst. Tech. 6 (1998).

[24] J. Cao, N. Krishnan, Z. Wang, H. Lu, W. K. Liu and A. Swanson, Trans. ASME 126 (2004) 642 652.

[25] P. Tiernan, M.T. Hillery, B. Draganescu and M. Gheorghe, J. Mat. Proc. Tech. 168 (2005) 360-366.

[26] J. Maciejewski, H. Kopeć and H. Petryk, Eng. Trans. 55 (2007) 197-216.

[27] S. Li, M.A.M. Bourke, I.J. Beyerlein, D.J. Alexander and B. Clausen, Mat. Sci. Eng. A 382 (2004) 217-236.

[28] M. Prakash and P. W. Cleary, CSIRO, Melbourne, Australia, 2006.

[29] S. Lou, G. Zhao, R. Wang and X. Wu, J. Mater. Process. Technol., 206 (2008) 481-490. 